\section{International Journal of Community Development \& Management Studies}

John Molson

School of Business

Concordia University
A Partner Publication

of the Informing Science Institute

InformingScience.org

Volume 1, 2017

IJCDMS.org

\title{
IDENTIFYING BARRIERS TO INTEGRATION OF TECHNOLOGY INTO TRADITIONAL APPROACH OF TEACHING: A CASE STUDY OF MATHEMATICS TEACHERS IN FORMER TRANSKEI IN THE EASTERN CAPE
}

Agyei Fosu*

* Corresponding author

\author{
Walter Sisulu University, East Lon- \\ afosu@wsu.ac.za
} don, South Africa

\begin{abstract}
Aim/Purpose

The main aim of the study is to identify some of the barriers to the integration of technology into the teaching of mathematics in high schools.

Background

Writing on chalkboards as a method of transferring knowledge is a key feature of traditional approach to teaching may have been successful in the past, but the minds of the current generation vary from those of the previous generation. Today's students are immersed in technology. They are much more up-todate on the latest technology and gadgets. Technology has certainly changed how students access and integrate information, so it plausible that technology has also changed the way students thinks. Growing up with cutting-edge technologies has left them thinking differently than students of past generations. This call for new innovative approaches to teaching that will cater to the students of today. Of course it is not wise to discard the traditional way of teaching that the past teachers have painstakingly created because of its past and some current success. This is why it is recommended to use this approach as a base for the new ones. Thus, if there is a way to transfer the advantages of this approach of teaching to new innovative approach then teachers should do everything in their power to merge the past and the present into one innovative teaching approach.
\end{abstract}

Methodology Purposeful sampling was used to survey a total of 116 high school mathematics teachers in the former Transkei Homelands. But only 97 questionnaires were deemed usable because of the way they have answered the questions. Microsoft excel was used in the descriptive statistics

Contribution To identify some barriers that need to be addressed by stakeholders, policy

Accepting Editor: Clarence S Bayne | Received: June 02, 2017 | Revised: August 15 and September 14, 2017 | Accepted: October 26, 2017.

Cite as: Identifying barriers to integration of technology into traditional approach of teaching: A case study of mathematics teachers in former Transkei in the Eastern Cape. Informing Science: International Journal of Community Development \& Management Studies, 1, 39-47, Retrieved from: http://ijcdms.org/Volume01/v1p063071Fosu3785.pdf

(CC BY-NC 4.0) This article is licensed to you under a Creative Commons Attribution-NonCommercial 4.0 International License. When you copy and redistribute this paper in full or in part, you need to provide proper attribution to it to ensure that others can later locate this work (and to ensure that others do not accuse you of plagiarism). You may (and we encourage you to) adapt, remix, transform, and build upon the material for any non-commercial purposes. This license does not permit you to use this material for commercial purposes. 


\section{Identifying barriers to integration of technology....}

Findings

Recommendations for Practitioners

Recommendation for Researchers Impact on Society

Future Research makers in high school education so that high school mathematics teachers will be able to integrate technology into their classroom teaching to meet today students' learning needs.

The results indicated that the participating teachers need to be trained and supported in the use of the new technologies applicable to teaching mathematics.

The Eastern Cape department of education needs to consider the lacked of technology training as a barrier to the integration of technology into the teaching of mathematics and take necessary steps to address it.

There is the need to explore in depth whether the factors of gender and age also act as barriers.

The research will assist stakeholders, policy makers of high school education to identify the needs of mathematics teachers. That is to say, the skill sets, experience and expertise, as well as teaching equipment and classroom design and environment required by mathematics teachers.

More work needs to be done to check whether gender, age of the teachers have some effects on their attitude towards technology integration as well as evaluate the role played by choice of teaching methodology and teaching objectives.

Keywords Mathematics teachers, technological skills, training

\section{INTRODUCTION}

It is a known fact that teachers are the locus and disseminators of knowledge when it comes to high school education, Killen (2007: 366-367) defined for us the seven roles of teachers and stated clearly in the first, second and the seventh roles that the teacher should be well grounded in the knowledge, know about the different approaches to teaching and learning and how these may be used in ways which are appropriate to the learner and context. However, researchers such as Gardner (2006), Wagner (2006) and others have questioned with great concern how the approaches used by our schools in teaching classroom are helping and preparing students for the $21^{\text {st }}$ century the digital age literacy. Writing on chalkboards a key feature of traditional approach of teaching may have been successful in the past, but the minds of the current generation vary from those of the previous generation. Today's students are immersed in technology. They are much more up-to-date on the latest technology and gadgets. Technology has certainly changed how students access and integrate information, so it plausible that technology has also changed the way students thinks. As a result of them growing up with cutting-edge technologies has left them thinking different than students of past generations. This call for new innovative approaches of teaching that will cater specially to the students of today. Of course it is not wise to discard the traditional way of teaching that the past teachers have painstakingly created because of its past and some current incredibly success. This is why it is recommended to use this approach as a basis for the new ones.

But if there is a way to transfer the advantages of this approach of teaching to new innovative approach then teachers should do everything in their power to merge the past and the present into one innovative teaching approach. Integration of technology into teaching affords us the opportunity to merge the past and the present to cater for students of today. 
Unfortunately, most of our current mathematics teachers still follow only the traditional approach of teaching. As a result of this approach of teaching mathematics, many students are discouraged from developing interest in the subject and rather consider it as boring, abstract and hence will developed a negative attitude towards the subject. These challenges, poses a great danger not only for the country's economic growth but the type of skilled learners that will be produced for the labor force in the country. This is because lack of numerical competences (Jenkins 2009) has a negative effect on employment and economic development in the $21^{\text {st }}$ century economies.

This places a great responsibility on our mathematics teachers to improve their approach of teaching this critical subject.

\section{BACKGROUND}

During the reign of former South Africa apartheid system, land was set aside for black people in selfgoverning territories. Ciskei and Transkei was designated as two homelands for Xhosa-Speaking people. Butterworth, Mthatha, Cofimvaba, Bisho, Engcobo, Libode, Lusikisiki, Maluti, Dutywa, are some of the major towns that were in the former Transkei homeland.

The two regions are underdeveloped in infrastructure and characterized by high levels of unemployment, poverty and crime which impact negatively on the economy. Different types of schools such as village, farm, township and town schools exist in the regions with a large number of village schools in the former Transkei and over populated with learners who belonged to single headed households or have no parents and also one of the areas underperforming when it comes to national matric results (Thobeka 2014).

Quality education therefore become vital to the region because is one of the tools that can be used in empowering people and improving the standards of living in underdeveloped regions. As highlighted by Nussbaum 2011(in Meyer 2014) education not only gives one a qualification but converts people's existing capacities into developed internal capabilities of many kinds. This formation, thus serves as a basic necessity which positions one to have competencies and confidence to participate, contributes in the economy sector trained in which is central to functioning of a society (Unterhalter 2013).

\section{PROBLEM STATEMENT}

For modern day students one of the ways to innovatively improve the traditional approach of teaching is the incorporation of technology in day to day lessons (Fulton 2012). This can be achieved either by using it as a teaching aid in classroom or giving assignments which require students to search information on internet and by so doing may come across various demonstrations, applications on the topic. But as pointed out in the work of Ertmer 2005 that embracing and using knowledge including a skill in teaching by teachers will only happen if it is consistent with their existing pedagogical beliefs.

The study of Stuart and Tatto (2000), Tatto (2007) have reveal the lack of emphasis on information technology and computer training in most teacher education programs and in some cases, the fact that teachers graduate from programs with little or no knowledge of information technology and computer training presents a troubling trend regarding the level of technological knowledge teachers may hold. A major question arises: Is it lack of technological skills and technological tools such as Laptops, Computers, Tablets, Projectors, Internet connectivity, etc or is it the mind set of following the way it has been done that serves as a barrier to integration of technology to the teaching of mathematics in high schools? This study set out to find some answers to these questions.

The study will investigate the following:

- The technological skills of the teachers. 
- The willingness of the teachers to shift from the traditional approach (use of chalkboard only) to embracing and incorporating technology.

\section{RESEARCH DESIGN AND METHODOLOGY}

The study only focused on mathematics teachers of the former Transkei homeland in the Eastern Cape, thus making it a regional-specific study. Mathematics teachers from other former homelands of South Africa, which were outside the targeted geographical area, were excluded due to time and financial constraints.

The choice of research and sampling techniques by a researcher are governed by the nature of information/evidence required (Welman and Kruger (2001)). Quantitative research was deemed appropriate for this study. Purposeful sampling was employed to select a sample of 116 high schools from database of Eastern Cape Department of Education of high schools in former Transkei homeland.

The following questions guided the study guided and the design of the questionnaire:

- Their gender

- How long they have been teaching mathematics in high school?

- The year they obtained their qualification

- If they have a Laptop, Tablet, mobile phone with internet access? If no can they afford one?

- If they have received any training in technological skills like internet usage, Microsoft word, Excel, PowerPoint and are confident of using the program?

- How often they do search internet (on their Laptop, mobile phone or Tablet) for demonstrations and applications on some of the mathematics topics they teach their students and show it to them?

- Do their students have access to internet example internet café, cell phone with internet access?

- How often do they ask their students to search on internet (on their own) for problems or solutions on some of the mathematics topics they teach them?

- Given training on how to incorporate technology and technological tools like Laptop, projector for teaching mathematics and writing on chalkboards which one will they prefer and why?

- In their opinion, what is the best approach to teach mathematics (Chalkboard only or infusion of technology)?

A questionnaire was developed and sent to ask the mathematics teachers in the chosen schools, about their skills in some basic computer end-user programs as well as internet access and how frequently they use internet to engage students. Respondents were assured of confidentiality of their responses in the letter that was attached to the questionnaires by highlighting to them that their names or the names of the schools would not be mentioned to ensure that reliable information would be given. A total of 112 usable questionnaires were finally obtained but 97 were deemed usable because they were the once who have answered the questions to the satisfaction of the researcher. Descriptive statistics were used in the study.

\section{THE SURVEY AND THE PARTICIPANTS}

The researcher decided to restrict the selection of participants based on their teaching post location, which is only mathematics teachers who are teaching in the towns selected for the study. 


\section{DATA PRESENTATION AND DISCUSSION}

Mallows and McNeil (2005:5) assert that, in order for teachers to address needs more effectively, they need to upgrade their skills of presenting lessons and subject knowledge. This assertion became an essential requirement when in 2003 South Africa implemented the National Curriculum Statement which saw the movement from an emphasis on learning content to specific outcomes and from the memorizations of facts to the demonstrations of outcomes (Department of Basic Education 2012). The movement did require from our teachers the immediate shift from the traditional approach of teaching. Such shift needed to have been initiated by the management within the department of education to first identify the likely barriers to the shift and come up with a program of action to deal with them before the implementation. Some of the obvious likely barriers that needed to have been picked up were the skills to implement the new curriculum and the willingness of the teachers to let go of the way it has been done.

The complexity of the practice of teaching is made clear by Mishra and Koehler 2006. Therefore, the practice requiring teachers to interweave complex and different kind of specialized knowledge structures and skills across different cases and contexts (Mishra and Koehler 2006, Mishra et. al. 1996). Technology has become one of the skills required in the $21^{\text {st }}$ century digital age. In 2007 Mishra and Koehler answered the worrying question about how to integrate technology into teaching by proposing that correctly linking the relationship between the three core components (Content Knowledge, Pedagogy Knowledge and Technological Knowledge: see Mishra and Koehler 2007 for more details) teachers must have, will lead to good integration of technology into teaching. Which also suggest if one or more of the three core component is lacking there will be difficulty in the integration process.

\section{RESEARCH HYPOTHESIS}

After a review of the work of Mishra et al. 2007, the following hypothesis was constructed and tested to make statistical inferences about the population based on the data collected. Mishra et al. 2007 suggested that one of the three core components required by teachers for the successful integration of technology into their day to day teaching is a technological skill.

Hypothesis: Teachers' willingness to integrate technology into their day to day teaching of mathematics is affected by their technological skills.

\section{RESULTS}

The results of the current study provided some interesting information regarding the skills and the willingness of the teachers to let go of how things have been done. The demographic profile of participants were asked and reported in Table 1. More than half of the participants are male $(n=71)$.

Table1: Demographic profile of the participants

\begin{tabular}{|l|c|c|}
\hline Gender & Frequency & Percentage \\
\hline Male & 71 & 73.20 \\
\hline Female & 26 & 26.80 \\
\hline
\end{tabular}

The participants were also asked about in terms of years teaching mathematics in high school and reported in Table 2. Majority of the participants had 11 years and above teaching experience $(n=49)$.

Table 2: Experience $(\mathrm{N}=97)$

\begin{tabular}{|l|c|c|}
\hline Years of teaching mathematics & Frequency & Percentage \\
\hline $1-5$ & 15 & 15.46 \\
\hline $6-10$ & 33 & 34.02 \\
\hline
\end{tabular}


Identifying barriers to integration of technology....

11 and above

49

50.52

In terms of period of obtaining their qualification it can be seen in Table 3. Majority of respondent fall within the period 1990-2006 ( $\mathrm{n}=31)$.

Table3: Year of participants obtaining their qualification

\begin{tabular}{|l|c|c|}
\hline Year & Frequency & Percentage \\
\hline $1973-1989$ & 54 & 55.67 \\
\hline $1990-2006$ & 31 & 31.96 \\
\hline $2007-2015$ & 12 & 12.37 \\
\hline
\end{tabular}

As can be seen, Table 4 presents the technological skills of the participants in terms of types of technical skills and methods of skills acquisitions.

Table 4: Technological skills $(\mathrm{N}=97)$

\begin{tabular}{|l|c|c|c|c|c|c|}
\hline & No Training & \% & Self Taught & \% & Trained & \% \\
\hline $\begin{array}{l}\text { Microsoft } \\
\text { word }\end{array}$ & 60 & 61.86 & 31 & 31.96 & 6 & 6.19 \\
\hline $\begin{array}{l}\text { Microsoft } \\
\text { Excel }\end{array}$ & 86 & 88.66 & 7 & 7.22 & 4 & 4.12 \\
\hline PowerPoint & 94 & 96.91 & 2 & 2.06 & 1 & 1.03 \\
\hline Internet & 82 & 84.54 & 15 & 15.46 & - & - \\
\hline
\end{tabular}

The distribution of participants having Laptops, Tablets, Mobile Phone; distribution of participants responding yes or no to whether they believe students have internet access; and whether they search internet for demonstrations and applications are reported in Table 5.

Table 5: Teachers having Laptops, Tablets, mobile phone with internets access and search on internet for demonstrations, applications $(\mathrm{N}=97)$

\begin{tabular}{|l|c|c|c|c|}
\hline & Yes & $\mathbf{\%}$ & $\mathbf{N o}$ & $\mathbf{\%}$ \\
\hline Laptops & 58 & 59.79 & 39 & 40.21 \\
\hline Tablets & 17 & 17.53 & 80 & 82.47 \\
\hline Mobile phones & 97 & 100 & 11 & 11.34 \\
\hline $\begin{array}{l}\text { Believe students have } \\
\text { access to internet }\end{array}$ & 86 & 88.67 & 95 & 97.94 \\
\hline $\begin{array}{l}\text { Search demonstrations, } \\
\text { applications and shown } \\
\text { to students(Once) }\end{array}$ & 2 & 2.06 & & - \\
\hline
\end{tabular}

In terms of participants' years of usage of technology to engage students is presented in Table 6. This study reveals that more than half of the participants $(n=91)$ have never use technology to engage students.

Table 6: Usage of technology to engage students $(\mathbf{N}=97)$

\begin{tabular}{|l|c|c|}
\hline Frequency & Number of teachers & $\mathbf{\%}$ \\
\hline Once in a year & 6 & 6.19 \\
\hline Once in a term & - & - \\
\hline Have never & 91 & 93.81 \\
\hline
\end{tabular}

The reasons and willingness of the participants to use technological tools as opposed to chalkboards in their day to day teaching of mathematics is reported in Table 7. The results from Table 5 show that half of the participants prefer chalkboards than technological tools. 
Table 7: Use of technological tools against chalkboards ( $N=97)$

\begin{tabular}{|c|c|c|c|}
\hline & Yes & $\%$ & Reasons \\
\hline Chalkboards & 52 & 53.61 & (1)Not use to it.(Not liking to use technology) \\
\hline Technological tools & 45 & 46.39 & $\begin{array}{l}\text { (2)Will be time consuming to gather notes.(Not } \\
\text { liking to use technology) } \\
\text { (3)Will save time and energy.(Like to use tech- } \\
\text { nology) } \\
\text { (4) That is the way we were taught (Not liking to } \\
\text { use technology) }\end{array}$ \\
\hline
\end{tabular}

The opinions of the participants about the best approach in teaching mathematics were asked and the results presented in Table 8 . Table 8 shows $(\mathrm{n}=51)$ of the participants believing using chalkboards only is the best approach.

Table 8: Best approach in teaching mathematics $(\mathbf{N}=97)$

\begin{tabular}{|l|c|c|}
\hline Using Chalkboards only & 51 & $52.58 \%$ \\
\hline $\begin{array}{l}\text { Incorporating technology \& Tech- } \\
\text { nological tools }\end{array}$ & 46 & $47.42 \%$ \\
\hline
\end{tabular}

\section{RESULTS DISCUSSION}

The results of this study reveal the skills of the participants in the use of basic technologies applicable to integration of technology into day to day teaching of mathematics. Findings from (see Table 4) accept the hypothesis that the willingness of the teachers to integrate technology in their day to day teaching will be affected by the lack of technological skills. The p-value for (see Table 7) is 0.47724 which further suggest the hypothesis cannot be rejected. One will not be far from the truth to say the percentages of no training from table 4 suggests that the teachers are lacking the Technology Knowledge to integrate technology into teaching and is one of the major reasons why these teachers are not using technology to engage the students although most students have access to internet as shown in the results of Table 5 and 6.Furthermore, the results confirm the point highlighted by Ertmer 2005 that using knowledge and skills in teaching will happen if it is consistent with their existing pedagogical beliefs.

\section{CONCLUSION AND RECOMMENDATIONS}

The researcher set out to investigate the technological skills and the willingness of the teachers to shift from the traditional approach (use of chalkboard only) to embracing and incorporating technology into their day to day teaching of mathematics. The research has revealed the need for Eastern Cape Department of Education to provide technological tools such as Tablets, Laptop and practical technological skills (see results in Table 2) development training, as well as find ways and means of upgrading the knowledgebase of teachers (see results in Table 6) and technological skills that can be incorporated into their day to day teaching in order to meet the needs of modern day students and change mindsets in their classrooms about learning and achievement from fixed to growth. These problems need to be addressed by encouraging additional training in information technology, providing the necessary technological tools and internet access for the teachers by Eastern Cape Department of Education, and encouraging the use of technology to engage students. These objectives can be achieved by Eastern Cape Department of Education partnering with the various Computer Science and Information Technology Departments within the Universities in the Eastern Cape Province to design and run short courses/workshops for the teachers. More work needs to be done to check whether gender, age of the teachers have some effects on their attitude towards technology integration. 


\section{Identifying barriers to integration of technology....}

\section{REFERENCES}

Department of Basic Education (2012). Special Report.: Big decline in numbers of matric maths passes-Equal Education. Pretoria: Department of Education.

Ertmer, P. A. (2005). Teacher pedagogical beliefs: The final frontier in our quest for technology integration?. Educational technology research and development, 53(4), 25-39.

Fulton, K. (2012). Upside down and inside out: Flip your classroom to improve student learning. Learning \& Leading with Technology, 39(8), 12-17.

Gardner, H. (2006). Multiple intelligences: New horizons (Rev. ed.). New York, NY: A Member of the Perseus Books Group.

Jenkins, H., Purushotma, R., Weigel, M., Clinton, K., \& Robison, A. J. (2009). Confronting the challenges of participatory culture: Media education for the 21st century. Mit Press.

Killen, R. (2007). Teaching strategies for outcomes-based education. Juta and Company Ltd.

Mallows, D., \& McNeill, R. (2005). Special report numeracy. The Magazine of NRDC, 1(2), 01 February.

Meyer, M. F. (2014). The relationship between quality of life, education, and poverty and inequality in South Africa: The capability approach as an alternative analytical framework (Doctoral dissertation, University of Western Cape).

Mishra, P., Spiro, R. J., \& Feltovich, P. J. (1996). Technology, representation, and cognition: The prefiguring of knowledge in cognitive flexibility hypertexts. Advances in discourse processes, 58, 287-305.

Mishra, P., \& Koehler, M. J. (2007, March). Technological pedagogical content knowledge (TPCK): Confronting the wicked problems of teaching with technology. In Society for Information Technology \& Teacher Education International Conference (pp. 2214-2226). Association for the Advancement of Computing in Education (AACE).

Mishra, P., \& Koehler, M. J. (2006). Technological pedagogical content knowledge: A framework for teacher knowledge. Teachers college record, 108(6), 1017.

Nussbaum, M. C. (2011). Creating capabilities: The human development approach. Harvard University Press.

Stuart, J. S., \& Tatto, M. T. (2000). Designs for initial teacher preparation programs: an international view. International Journal of Educational Research, 33(5), 493-514.

Tatto, M. T. (2006). Education reform and the global regulation of teachers' education, development and work: A cross-cultural analysis. International Journal of Educational Research, 45(4), 231-241.

Ncanywa, T. (2014). The state of the Eastern Cape schools in a period almost the second decade of democracy. ERSA Working Paper 486, (December).

Unterhalter, E. (2013). Educating Capabilities. Journal of Human Development and Capabilities, 14(1), 185-188.

Wagner, T. (2014). The Global Achievement Gap: Why Even Our Best Schools DonÕt Teach the New Survival Skills Our Children NeedÑand What We Can Do About It. Basic Books.

Welman, J. C., \& Kruger, S. J. (2001) Research Methodology, 2nd Ed. Oxford University, Cape Town. 


\section{BIOGRAPHY}

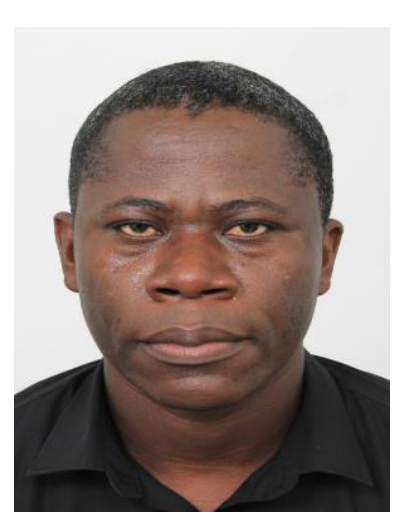

Agyei Fosu is a lecturer in the Department of Information Technology at the Walter Sisulu University where he teaches Information Technology Skills as well as mathematics for IT. He is actively involved in technology in education research. 